\title{
EFFECTS OF ORAL AND VAGINAL ADMINISTRATION OF PROBIOTIC BACTERIA ON THE VAGINAL MICROBIOTA AND CYTOKINES PRODUCTION IN THE CASE OF EXPERIMENTAL STAPHYLOCOCCOSIS IN MICE
}

\author{
L.M. Lazarenko ${ }^{1}$ L.P. Babenko', V.V.Mokrozub ${ }^{1}$, O.M. Demchenko', \\ V.V. Bila', M.Ya. Spivak ${ }^{1,3}$ \\ ${ }^{1}$ Zabolotny Institute of Microbiology and Virology, National Academy of Sciences of Ukraine, \\ 154, Ak. Zabolotny St., Kyiv, 03143, Ukraine \\ ${ }^{2}$ Perinatal Center, 9, Predslavinskaya St., Kyiv, 03150, Ukraine \\ ${ }^{3} L C L \ll D I A P R O F », 35$, Svitlyskoho St., Kyiv, 04123, Ukraine \\ LazarenkoLM@gmail.com
}

Objective. The objective of this study was to elucidate the effects of the probiotic strain Lactobacillus casei IMV B-7280 and L. casei IMV B-7280 - Bifidobacterium animalis VKL - B. animalis VKB (Lc - VKL - VKB) or B. animalis VKL - B. animalis VKB $(V K L-V K B)$ strain compositions that administrated both orally and vaginally or only orally, on the vaginal microbiota and cytokines production in experimental vaginal staphylococcosis in BALB/c mice. Methods. Probiotic bacteria administrated into staphylococcus-infected mice vaginally and orally simulntaneously or only orally. Material from the vagina was plated on selective media; the number of colony forming units was counted. The concentration of cytokines in the blood serum of mice was determined by enzyme immunoassay method. Results. It was found, that the number of aerobic and facultative anaerobic microorganisms in the vagina of staphylococcus-infected mice was decreased after administration of these probiotic bacteria or its compositions both into vagina and orally or only orally. The increase in the number of lactic acid bacteria (LAB) and bifidobacteria in the vagina of these mice was also observed. However, the number of coliform bacteria and microscopic fungi was smaller and the number of $L A B$ was greater after administration of L. casei IMV B-7280 or Lc - VKL - VKB and VKL - VKB compositions into staphylococcus-infected mice vaginally and orally simultaneously, compared to only oral administration. A change of the vaginal microbiota of staphylococcus-infected mice that received these probiotic bacteria was accompanied with higher level of interferon- $\gamma$ and interleukine-12 production, which favors the development of Th1 immune response and decrease of the production of pro-inflammatory cytokine tumor necrosis factor- $\alpha$. The immunomodulatory effectiveness of L. casei IMV B-7280 and Lc - VKL - VKB composition will also be higher if they are administered into staphylococcus-infected mice both orally and vaginally than only orally.

Conclusions. Probiotic strain L. casei IMV B-7280 and Lc - VKL - VKB or VKL-VKB strain compositions can be a good candidate for the creation of immunobiotics for treatment of urogenital infections.

Keywords: lactic acid bacteria, bifidobacteria, microbiota, vagina, staphylococci, cytokines, mice.

Traditionally, probiotics, based of commensal microbiota, in particular lactic acid bacteria (LAB) and bifidobacteria, are widely used for the treatment and prevention of intestinal or vaginal microbiota imbalance in many infectious and non-infectious human diseases $[1,2,3,4]$. Most studies have shown the favor 
of probiotics in the prevention or treatment as alternatives or co-treatments of urogenital infections in adults and children. Although antibacterial therapy using antibiotics is usually effective, a high frequency of relapses of urogenital infections and increasing microbial resistance are observed due to the multiple use of antimicrobial drugs, that justify the search for new approaches for treatment of patients. So, it has been shown that probiotics, including some selected strains of Lactobacillus may be an effective strategy to prevent bacterial vaginosis, urinary tract infections, vulvovaginal candidiasis, papillomavirus infection, etc. $[1,5,6,7]$. It was also justified the joint use of probiotics with antibiotics in the treatment of bacterial vaginosis for more effective microbiota restoring in the urogenital tract [8].

However, a number of experimental and clinical studies demonstrated that some probiotic strains of $\mathrm{LAB}$ and bifidobacteria are able to effect the immune response in infectious, allergic, neoplastic and other diseases, therefore, they can be used to create high-efficient immunobiotics. So, these probiotic strains activated the innate (increased the activity of dendritic cells, neutrophils, macrophages, natural killer cells etc.) and adoptive immunity, and altered the production of the Th1 (interferon- $\gamma$ (IFN- $\gamma$ ), interleukin-2 (IL-2), IL-12, tumor necrosis factor- $\alpha$ (TNF- $\alpha$ ) etc.) or Th2 (IL-4, IL-10 etc.) type cytokines, which determine, in what direction the immune response will develop - humoral or cellular $[9,10]$. Th1 cells and Th1 type cytokines play crucial roles in host health against viral and bacterial infections, alleviate allergic diseases and suppress tumors [11]. It should be noted that immunomodulatory properties of LAB and bifidobacteria are species- and strain-specific. Different species or variants within the same species can interact with the immune system on local or systemic levels in different ways [10]. Probably the mode of administration of these probiotic strains is also important. Thus, before LAB and bifidobacteria strains using as immunobiotics, it is nessesary to carefully examine the mechanisms of their immunomodulatory action in various experimental conditions.

We previously found that the probiotic strains Lactobacillus casei IMV B-7280, Bifidobacterium animalis VKL and B. animalis VKB had antistaphylococcal and immunomodulatory efficacy in the case of experimental staphylococcosis in BALB/c mice. After administration of these probiotic bacteria or compositions with its presence into vagina of staphylococcusinfected mice, the normalization of the vaginal microbiota, as well as the activation of the cellular immune response were observed [12].

The objective of this study was to elucidate the effects of oral or oral and vaginal administration of probiotic strain $L$. case $i$ IMV B-7280 and $L$. case $i$ IMV B-7280 - B. animalis VKL - B. animalis VKB (Lc - VKL - VKB) or $B$. animalis $\mathrm{VKL}-B$. animalis $\mathrm{VKB}$ (VKL - VKB) compositions on the vaginal microbiota and cytokines production in the case of experimental staphylococcosis in mice.

Materials and methods. Experimental studies were performed on sixweek-old female BALB/c mice, synchronized in their estral cycle. All studies were performed taking into account the rules of the "European Convention for the protection of vertebrate animals used for experimental and other scientific purposes" (Strasbourg, 1986) and in accordance with "General ethical 
principles of experiments on animals". Mice were kept in standard vivarium conditions at a temperature of $22 \pm 1{ }^{\circ} \mathrm{C}$, they were provided with the full mixed feed and had free access to automatic water bowls.

The probiotic strains used were: L. casei IMV B-7280 (deposited in the Depositary of microorganisms of the D.K. Zabolotny Institute of Microbiology and Virology, NAS of Ukraine), B. animalis VKL and B. animalis VKB that isolated from content of gut of healthy people. The lyophilized probiotic bacteria were used in our study. The concentration of the LAB and bifidobacteria were tested by plating on the Man-Rogosa-Sharpe agar (MRSA) medium and Bifidum-agar (BA) in aerobic and anaerobic conditions respectively at $37^{\circ} \mathrm{C}$ for 24-48 $\mathrm{h}$ and prepeared suspension in phosphate-buffered saline (PBS) of given concentration.

Staphylococcus aureus strain 8325-4 (kindly provided to us by Professor V.S. Zuyeva, N.F. Gamaleya Institute of Epidemiology and Microbiology, Russian Federation), which contains the plasmid of resistance to gentamicin was chosen for modeling of the intravaginal staphylococcosis in mice. Suspension of the $S$. aureus strain 8325-4 daily culture in PBS was administered once into the vagina of BALB/c mice in the dose of $5 \times 10^{7}$ cells per animal. On the $1^{\text {st }}$ day after infection a suspension of $L$. casei IMV B-7280 (individually) or Lc - VKL - VKB, or VKL - VKB compositions (in equal proportions of each bacteria) in PBS was administrated into vagina or/and orally in a dose of $1 \times 10^{6}$ cells per animal, once a day for 7 days.

8 experimental groups were formed from BALB/c mice ( 12 mice in each group): 1) intact mice; 2) infected mice; 3) infected mice that obtained L. casei IMV B-7280 orally; 4) infected mice that obtained L. casei IMV B-7280 orally and vaginally; 5) infected mice that obtained VKL - VKB orally; 6) infected mice that obtained VKL - VKB orally and vaginally; 7) infected mice that obtained Lc - VKL - VKB orally; 8) infected mice that obtained Lc - VKL VKB orally and vaginally.

The material from vagina was collected using standardized sterile cotton tampons on the $1^{\text {st }}, 3^{\text {rd }}, 6^{\text {th }}, 9^{\text {th }}, 12^{\text {th }}$ and $30^{\text {th }}$ days after first administration of the probiotic bacteria. Swabs from each tampon were performed with $1 \mathrm{~mL}$ of $0.5 \mathrm{M} \mathrm{NaCl}$ and plated $0.1 \mathrm{ml}$ onto agar nutrient media: Meat-Peptone agar (MPA, medium for aerobic and facultative anaerobic bacteria), BAIRDPARKER-Agar (Merck, Germany; selective medium for staphylococci), KF-Streptococcus agar (Merck, Germany; selective medium for streptococci), ENDO (NSCAMB, Obolensk, Russia; selective medium for coliform bacteria), Sabouraud agar without antibiotics (selective medium for fungi), MRSA (selective medium for lactobacilli) and BA (selective medium for bifidobacteria). After cultivation at $37{ }^{\circ} \mathrm{C}$ for $24 \mathrm{~h}$, the number of colony forming units (CFU) was counted, given that one such colony corresponds to one bacterium. Swabs from the vagina were also plated on elective medium for staphylococci (BAIRD-PARKER-Agar, Merck, Germany) containing gentamicin at a concentration of $15 \mu \mathrm{g} / \mathrm{ml}$ to identify the growth of $S$. aureus strain 8325-4, which has a plasmid-based resistance to gentamicin, so unlike other strains of staphylococci it is able to grow on the medium with this antibiotic.

On the $1^{\text {st }}, 3^{\text {rd }}$ and $6^{\text {th }}$ days after probiotic bacteria administration the peripheral blood was taken from the tail vein of each mouse of all groups 
who had previously received anesthesia. We determined the concentration of cytokines in the blood serum of mice by enzyme immunoassay method (ELISA). Method was performed according to the manufacturer's recommendations (Thermo Fisher Scientific Inc. (Bender MedSystems GmbH), Austria). ELISA test kits for determination of mice IL-12 (p40 + p70), mice IFN- $\gamma$, mice TNF- $\alpha$ were used. The concentration of cytokines in serum was expressed as pg./ml.

All digital data received were processed with the help of the Epi Info software (version 6.0) through analysis of variance. Numerical data were represented as arithmetic average and standard error $(\mathrm{M} \pm \mathrm{m})$ using Student's t-test. The differences between the groups were considered statistically significant at $\mathrm{P}<0.05$.

Results. The acceleration of elimination of $S$. aureus strain 8325-4 from the vagina of staphylococcus-infected mice was observed after $L$. case $i \mathrm{IMV}$ B-7280 or Lc - VKL - VKB and VKL - VKB compositions oral and intravaginal or only oral administration compared with staphylococcus-infected mice that did not obtain probiotic bacteria (control group). We found that the antistaphylococcal efficiency of $L$. casei IMV B-7280 or Lc - VKL - VKB and VKL - VKB compositions depended on the mode of their administration into staphylococcus-infected mice (Fig. 1).

A

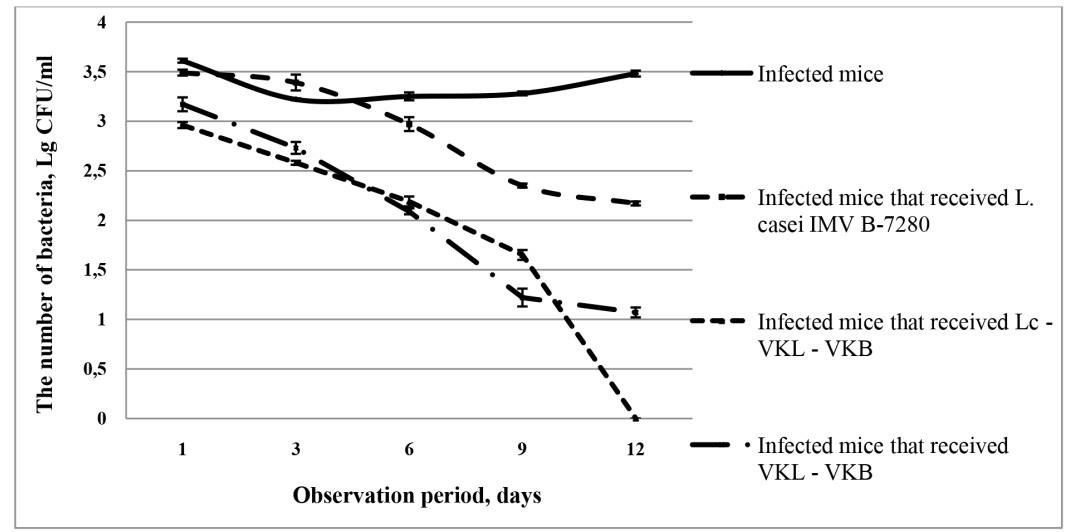

B

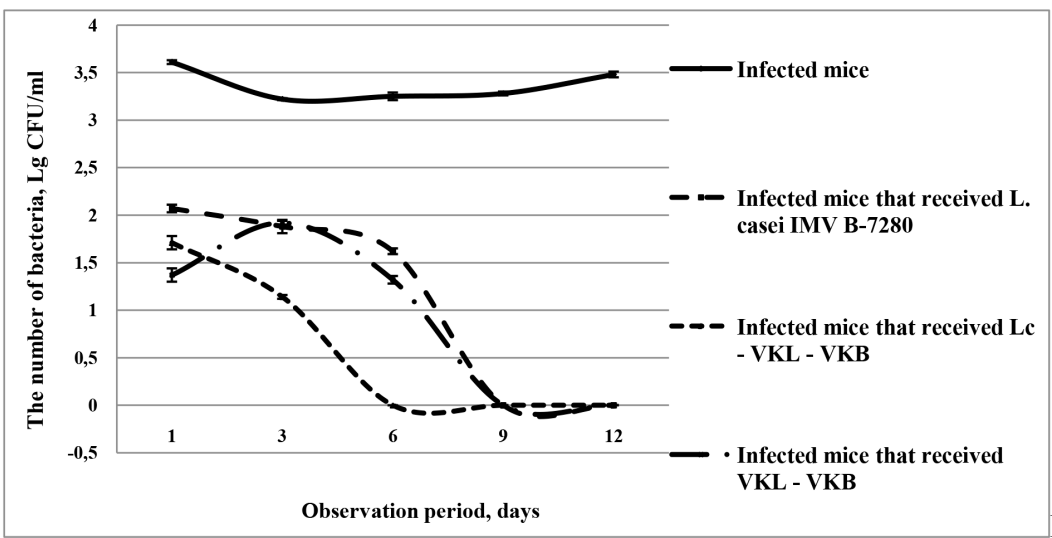

Fig. 1. The cell counts of $S$. aureus strain 8325-4 recovered from the vagina of infected BALB/c mice receiving $L$. casei IMV B-7280 or probiotic compositions orally (A) or orally and vaginally $(B)$ 
Complete elimination of $S$. aureus strain 8325-4 from the vagina was observed only on the $12^{\text {th }}$ day after oral administration of Lc - VKL - VKB composition. But, S. aureus 8325-4 was eliminated completely from the vagina of staphylococcus-infected mice after oral and vaginal administration of Lc - VKL - VKB composition on the $6^{\text {th }}$ day and L. casei IMV B-7280 or VKL - VKB composition on the $9^{\text {th }}$ day. Our data show that the antistaphylococcal efficiency of these probiotic bacteria was higher after simultaneous oral and vaginal administration into staphylococcus-infected mice than after only oral administration.

The number of aerobic and facultative anaerobic microorganisms, staphylococci, streptococci, coliform bacteria and microscopic fungi in the vagina of staphylococcus-infected mice was decreased after oral or simultaneous oral and vaginal administration of L. casei IMV B-7280 strain, as well as Lc - VKL - VKB or VKL - VKB compositions-compared with control group (Table 1). However, the number of coliform bacteria and microscopic fungi was more rapidly decreased after simultaneous vaginal and oral administration of probiotic bacteria than after only oral administration $(\mathrm{P}<0.05)$.

The increase in the number of LAB and bifidobacteria in the vagina of staphylococcus-infected mice that obtained these probiotic bacteria was also observed (Fig. 2). But, after vaginal and oral administration of $L$. casei IMV B-7280 or Lc - VKL - VKB and VKL - VKB compositions, the number of $\mathrm{LAB}$ was greater throughout the observation period (30 days) than after only oral administration $(\mathrm{P}<0.05)$. The level of $\mathrm{LAB}$ on the $30^{\text {th }}$ day wat the highest in the group of infected mice that obtained L. casei IMV B-7280 into vagina and orally. L. casei IMV B-7280 or Lc - VKL - VKB and VKL - VKB compositions increased the level of bifidobacteria in case of both vaginal and oral introduction throughout the observation period (30 days), but on the $30^{\text {th }}$ day the level of bifidobacteria was higher in the groups of infected mice that obtained Lc - VKL - VKB and VKL - VKB compositions into vagina and orally and VKL - VKB composition only orally.

Also we observed changes in the production of the Th1 type cytokines (IL-12 and IFN- $\gamma$ ) in different periods of observation (Table 2).

It should be noted that the level of IL-12 in the serum of staphylococcusinfected mice that did not obtain the probiotic bacteria or probiotic compositions was decreased on the $1^{\text {st }}$ day.

A slight decrease in the level of IFN- $\gamma$ in serum of these staphylococcusinfected mice was also observed throughout the observation period but the difference compared with the intact mice was not statistically significant. The infection with $S$ aureus strain 8325-4 also caused a significant increase in the level of TNF- $\alpha$ on the $3^{\text {rd }}$ day, which probably confirms the development of inflammation.

As shown in Table 2, the oral administration of L. casei IMV B-7280 into staphylococcus-infected mice did not affect the level of IL-12 in the serum throughout the observation period. But, the level of IFN- $\gamma$ in the serum of mice of this group was increased compared with control group throughout the observation period. At the same time, the level of IL-12 (throughout the observation period) and the level of IFN- $\gamma$ (on the $3^{\text {rd }}$ and $6^{\text {th }}$ days) were significantly higher in serum of staphylococcus-infected mice treated with 


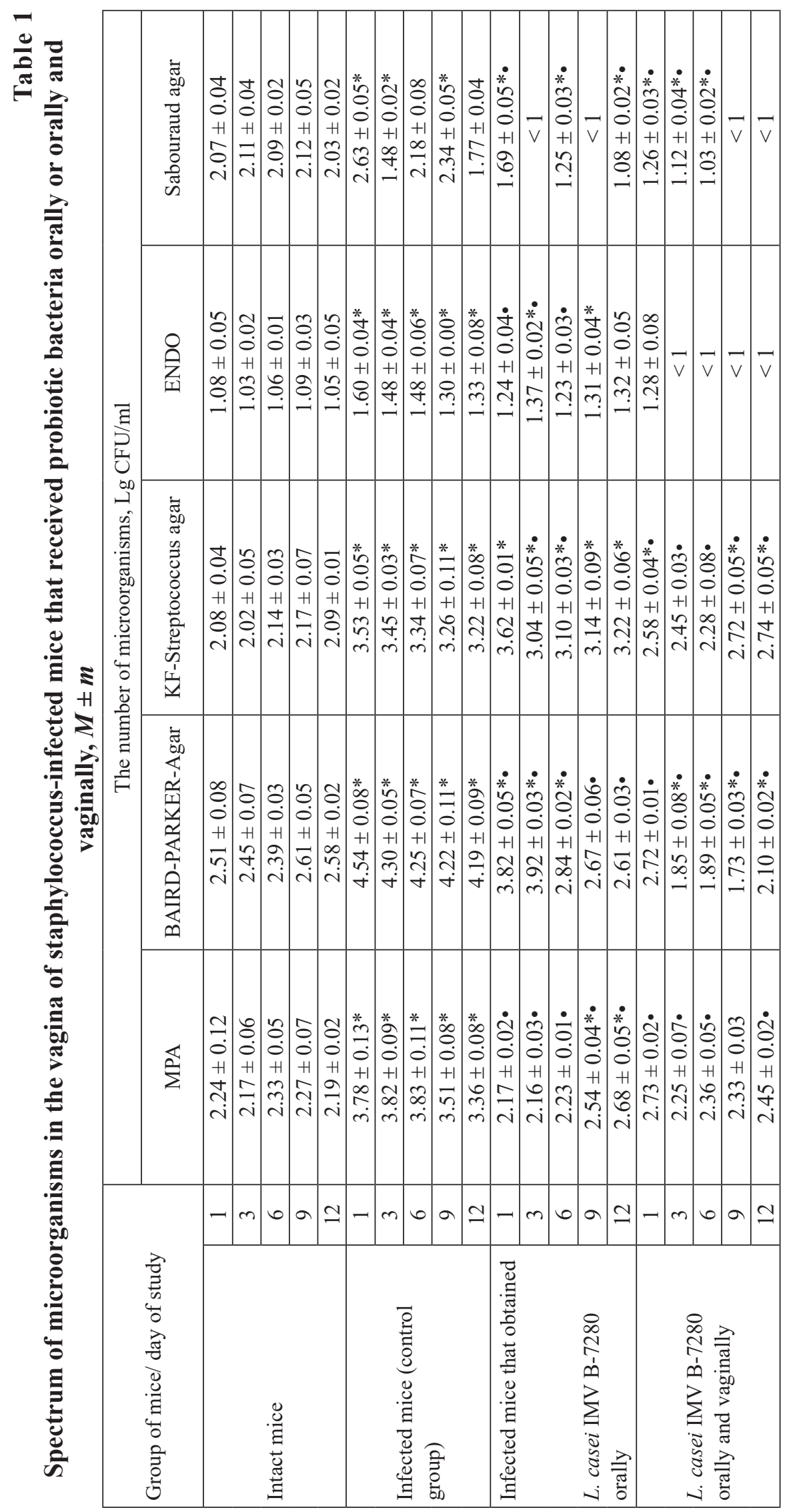




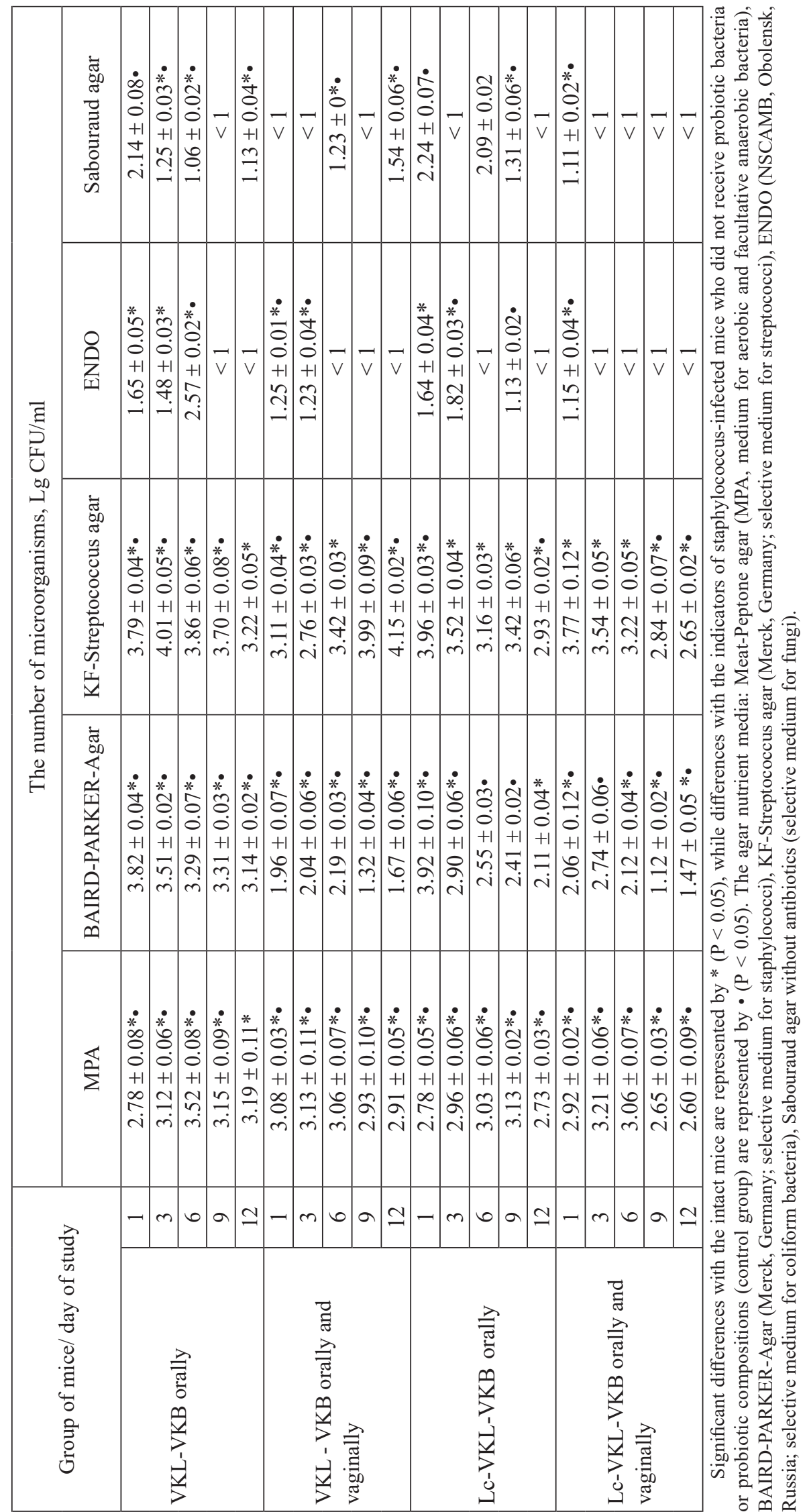


L. casei IMV B-7280 orally and vaginally than after this strain were administered only orally $(\mathrm{P}<0.05)$. We observed an increase in the levels of IL-12 (on the $1^{\text {st }}$ day) and IFN- $\gamma$ (on the $1^{\text {st }}$ and $6^{\text {th }}$ days) after oral administration of Lc VKL - VKB composition into staphylococcus-infected mice compared with control group. The increase in the levels of IL-12 (throughout the observation period) and IFN- $\gamma$ (on the $6^{\text {th }}$ and $9^{\text {th }}$ days) was more substantial in serum of staphylococcus-infected mice that obtained this probiotic composition orally and vaginally than only orally $(\mathrm{P}<0.05)$. On the contrary, in the case of using VKL - VKB composition for the treatment of staphylococcus-infected mice, the level of IL-12 (on the $1^{\text {st }}$ and $3^{\text {rd }}$ days) was higher if this composition was administered only orally than orally and vaginally. This probiotic composition increased the level of IFN- $\gamma$ on the $1^{\text {st }}$ and $6^{\text {th }}$ days and only on the $3^{\text {rd }}$ day if it

A

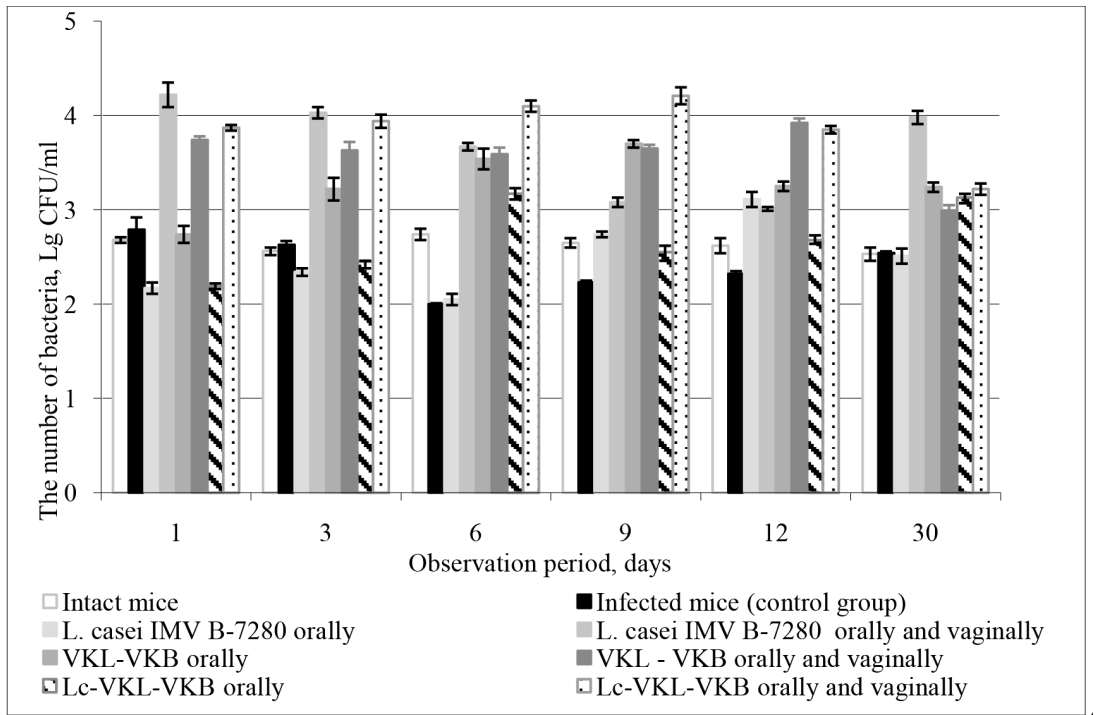

$\mathrm{B}$

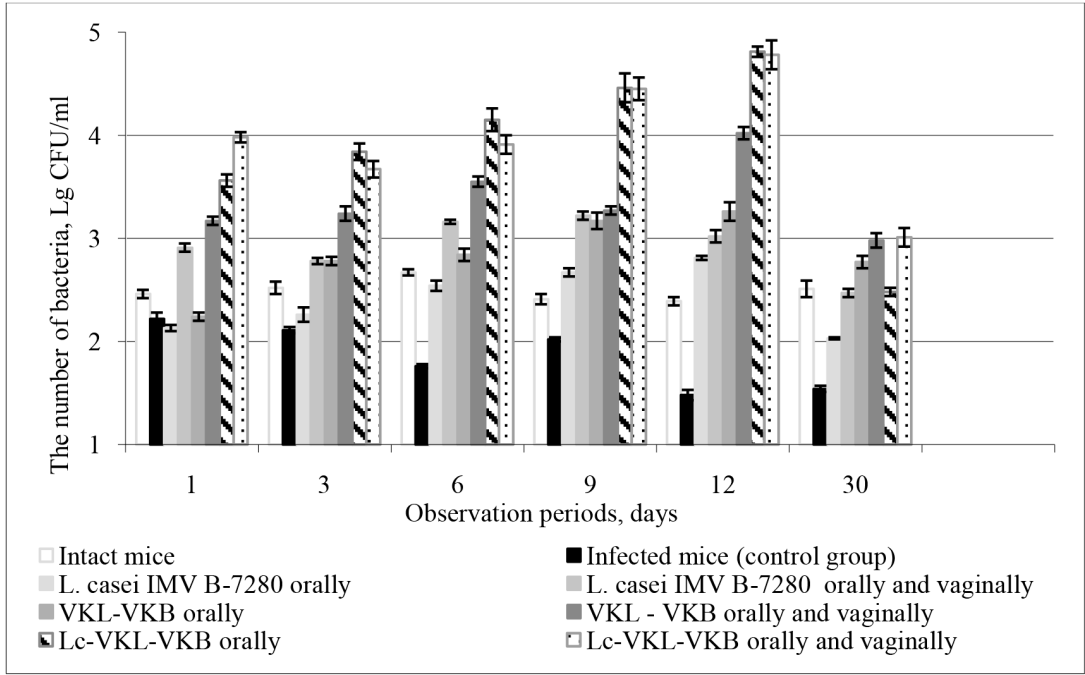

Fig. 2. The cell counts of $L A B$ (A) and bifidobacteria (B) recovered from the vagina of infected BALB/c mice receiving $L$. casei IMV B-7280 or probiotic compositions orally or orally and vaginally 
was administered orally or orally and vaginally respectively.

Additionally, the production of TNF- $\alpha$ was examined to confirm that these probiotic strains had anti-inflammatory effect in the case of experimental staphylococcosis. After their oral and vaginal or only oral administration into staphylococcus-infected mice, the level of the TNF- $\alpha$ significantly decreased or was not detected at all in the serum of mice from these experimental groups.

Our findings suggest that the elimination of $S$. aureus strain 8325-4 from the vagina and normalization of the vaginal microbiota of staphylococcus-infected mice that received L. casei IMV B-7280 and Lc - VKL - VKB or VKL - VKB compositions orally and vaginally or only orally occurs at higher level of IFN- $\gamma$ and IL-12 production, which favors the development of the Th1 type immune response, and decrease of the production of pro-inflammatory cytokine TNF- $\alpha$. It should be noted that the level of IFN- $\gamma$ significantly increased on the $3^{\text {rd }}$ day if $L$. casei IMV B-7280 or studied probiotic compositions were administered into staphylococcus-infected mice orally and vaginally compared with their oral administration.

Table 2

The cytokines level in the serum of infected mice that obtained probiotic bacteria, $M \pm m$

\begin{tabular}{|c|c|c|c|c|}
\hline \multirow[b]{2}{*}{ Groups of mice } & \multirow{2}{*}{$\begin{array}{l}\text { Observation } \\
\text { period after } \\
\text { injection of } \\
\text { probiotic } \\
\text { strains }\end{array}$} & \multicolumn{3}{|c|}{ Concentration of cytokine, pg./ml } \\
\hline & & IL-12 & TNF- $\alpha$ & IFN- $\gamma$ \\
\hline Intact mice & - & $613.8 \pm 56.9$ & $5.1 \pm 0.2$ & $3.7 \pm 0.5$ \\
\hline \multirow{3}{*}{$\begin{array}{l}\text { Infected mice } \\
\text { (control group) }\end{array}$} & 1 day & $350.9 \pm 11.9^{*}$ & $4.0 \pm 0.4$ & $2.1 \pm 0.6$ \\
\hline & 3 day & $678.8 \pm 32.1$ & $12.3 \pm 0.7^{*}$ & $2.3 \pm 0.6$ \\
\hline & 6 day & $587.3 \pm 42.9$ & $6.1 \pm 0.1$ & $2.7 \pm 0.9$ \\
\hline \multirow{3}{*}{$\begin{array}{l}\text { Infected mice that } \\
\text { obtained } \\
\text { L. casei IMV B-7280 } \\
\text { orally }\end{array}$} & 1 day & $385.6 \pm 13.7^{*}$ & $6.2 \pm 0.6$ & $22.1 \pm 0.2 * \bullet$ \\
\hline & 3 day & $760.0 \pm 44.3$ & $5.4 \pm 0.4$ & $8.2 \pm 0.3 * \bullet$ \\
\hline & 6 day & $625.5 \pm 52.4$ & 0 & $6.1 \pm 0.5 \bullet$ \\
\hline \multirow{3}{*}{$\begin{array}{l}\text { L. casei IMV B-7280 } \\
\text { orally and vaginally }\end{array}$} & 1 day & $618.3 \pm 47.9 \bullet$ & 0 & $12.1 \pm 0.7 * \bullet$ \\
\hline & 3 day & $855.8 \pm 38.0 * \bullet$ & 0 & $97.5 \pm 1.2 * \bullet$ \\
\hline & 6 day & $1365.3 \pm 76.8 * \bullet$ & 0 & $29.9 \pm 1.4 * \bullet$ \\
\hline \multirow{3}{*}{ VKL - VKB orally } & 1 day & $1045.0 \pm 65.3^{* \bullet}$ & $1.1 \pm 0.1^{*}$ & $11.3 \pm 0.2 * \bullet$ \\
\hline & 3 day & $1227.0 \pm 54.1 * \bullet$ & $2.6 \pm 0.4$ & $2.4 \pm 0.2^{*}$ \\
\hline & 6 day & $499.5 \pm 37.2$ & $6.1 \pm 0.2$ & $9.5 \pm 0.1 * \bullet$ \\
\hline \multirow{3}{*}{$\begin{array}{l}\text { VKL - VKB orally } \\
\text { and vaginally }\end{array}$} & 1 day & $855.6 \pm 25.4 * \bullet$ & 0 & $5.2 \pm 1.2$ \\
\hline & 3 day & $469.2 \pm 19.3 \bullet$ & 0 & $87.1 \pm 2.6^{*} \bullet$ \\
\hline & 6 day & $403.2 \pm 42.5^{*}$ & 0 & $2.3 \pm 2.2^{*}$ \\
\hline \multirow{3}{*}{$\begin{array}{l}\text { Lc - VKL - VKB } \\
\text { orally }\end{array}$} & 1 day & $454.3 \pm 13.7 \bullet$ & 0 & $36.0 \pm 0.4 * \bullet$ \\
\hline & 3 day & $615.3 \pm 23.9$ & 0 & $2.9 \pm 0.1$ \\
\hline & 6 day & $512.3 \pm 33.8$ & 0 & $12.0 \pm 0.5^{*} \bullet$ \\
\hline \multirow{3}{*}{$\begin{array}{l}\mathrm{Lc}-\mathrm{VKL}-\mathrm{VKB} \\
\text { orally and vaginally }\end{array}$} & 1 day & $1850.3 \pm 76.1 * \bullet$ & 0 & $7.4 \pm 0.6^{*} \bullet$ \\
\hline & 3 day & $1328.0 \pm 60.5^{* \bullet}$ & 0 & $85.5 \pm 0.5^{*} \bullet$ \\
\hline & 6 day & $865.6 \pm 59.3 * \bullet$ & 0 & $13.4 \pm 0.4^{* \bullet}$ \\
\hline
\end{tabular}

Significant differences with the intact mice are represented by $*(\mathrm{P}<0.05)$, while differences with the indicators of the staphylococcus-infected mice who did not receive probiotic bacteria or probiotic composition (control group) are represented by $(\mathrm{P}<0.05)$. 
Discussion. Today, many probiotic preparations are recommended for intravaginal use in the treatment of patients with urogenital infections $[1,6,13]$. Previously, clinical studies have shown that probiotic bacteria can be delivered to the vagina after oral intake [18]. It should be noted that the oral application of probiotics is more practical for the treatment of patients with urogenital infections, so it is a more effective strategy. That is why in our present studies we have investigated whether the L. casei IMV B-7280 and Lc - VKL - VKB or VKL - VKB compositions normalize the vaginal microbiota and affect the production of cytokines in case of their oral use in the model of vaginal staphylococcosis in mice. It was suggested that these probiotic bacteria after their oral administration, probably, are able to colonize not only the intestines but also the vaginal tract of staphylococcus-infected mice, and create less supportive environment for $S$. aureus strain 8325-4 and other pathogens survival by producing antimicrobial substances and stimulate the Th1 type immune response. Therefore, S. aureus strain 8325-4 elimination from the vagina and vaginal microbiota normalization as well as induction the production of the Th1 type cytokines at the system level were observed in staphylococcus-infected mice that were orally treated with the $L$. casei IMV B-7280 and Lc - VKL - VKB or VKL - VKB compositions.

Our data coincide with the data of other authors. So, recently has been reported that strains of $\mathrm{LAB}$, isolated from human or animal vagina or gut, have functional properties that can support their use as a potential probiotic for oral and vaginal applications $[14,15,16]$. These probiotic strains after oral application are able to colonize the vagina and effectively modulate vaginal microbiota and immunological profile. This was first proved for such strains as L. rhamnosus GR-1 and L. fermentum RC-14, that after oral administration were delivered to the vagina and effectively treated women with bacterial vaginosis $[17,18,19]$.

After oral application of the combination of three probiotic strains, L. fermentum 57A, L. plantarum 57B and L. gasseri 57C, with high adhesive ability to both vaginal and intestinal epithelial cells, also observed the colonization by them of a woman's vagina within a few weeks, which was associated with a significant improvement of parameters such as the total number of vaginal LAB, $\mathrm{pH}$ etc. [14]. The frequency of recurrence of bacterial vaginosis and aerobic vaginitis in women decreased after the use of oral probiotic preparation (prOVag ${ }^{\circledR}$ ) containing three strains of Lactobacillus together with a standard treatment with metronidazole, and targeted antibiotic treatment (after failure of metronidazole therapy). The reduced and maintained low vaginal $\mathrm{pH}$ and increased vaginal Lactobacillus number following this treatment were observed [20]. It should be noted that obviously there are differences in ability to colonize the vagina and intestines even for strains of the same species. Thus, it was found that $L$. rhamnosus GR-1 effectively colonized intestine and vagina, in contrast to the strain L. rhamnosus GG, which poorly 
colonizes vagina [21], but well colonizes intestine [22]. Oral use of probiotics may be useful for modulation of the vaginal microbiota and immunological profiles during pregnancy because violation of the vaginal microbiota is one of the most important mechanisms for preterm birth and perinatal complications [23].

But, in our studies we assumed that the antistaphylococcal effectiveness of L. casei IMV B-7280 or Lc - VKL - VKB and VKL - VKB compositions will be higher if they are administered simultaneous orally and vaginally. In the experimental model of vaginal staphylococcosis we have found that oral and vaginal administration of $L$. casei IMV B-7280 and Lc - VKL - VKB or VKL - VKB compositions into staphylococcus-infected mice was more effective in normalization of vaginal microbiota. $L$. casei IMV B-7280 and Lc - VKL - VKB composition more efficiently stimulated aslo Th1 type cytokine production after simultaneous oral and vaginal administration than only oral administration. But oral administration of VKL - VKB composition into staphylococcus-infected mice more effectivelly increased the IL-12 production than oral and vaginal separately.

L. casei IMV B-7280 has a high and B. animalis VKL and B. animalis VKB - an average adhesiveness to epitheliocytes [24]. Therefore, this difference in adhesiveness to epitheliocytes may be due to the increase in the ability of L. casei IMV B-7280 and its composition with bifidobacteria to colonize the epithelium of the vagina and gut after oral and vaginal administration to staphylococcus-infected mice. So, after oral and vaginal administration of Lc VKL - VKB composition we found more effective elimination of $S$. aureus strain 8325-4 from the vagina compared with VKL - VKB composition. Our analyses confirm that the study of the effectiveness of different methods of probiotic strains and their various compositions administration may be useful for their selection when creating immunobiotics.

Thus, L. casei IMV B-7280 and Lc - VKL - VKB or VKL - VKB compositions after oral as well as oral and intravaginal administration restored the microbiome of the vagina on the model of vaginal staphylococcosis in mice. This probiotic strains and their compositions are also should be regarded as immunomodulators, as it was evidenced the activation of Th1 type cytokines production after their use, so they can serve as support for an active immune system. However, simultaneous oral and vaginal administration of $L$. casei IMV B-7280 and Lc - VKL - VKB composition was more effective than oral. So, our results showed that the L. casei IMV B-7280 and Lc - VKL - VKB or VKL - VKB compositions can be a good candidate for the creations of immunobiotics for treatment of urogenital infections. However, additional studies regarding immunomodulatory properties of these probiotic bacteria are needed to confirm this. Such immunobiotics in the long term can also be used in the treatment of other infectious diseases. 


\title{
ДІЯ ПРОБІОТИЧНИХ БАКТЕРІЙ ПРИ ПЕРОРАЛЬНОМУ І ВАГІНАЛЬНОМУ ВВЕДЕННІ НА ВАГІНАЛЬНУ МІКРОБІОТУ \\ ТА ПРОДУКЦІЮ ЦИТОКІНІВ ЗА ЕКСПЕРИМЕНТАЛЬНОЇ СТАФІЛОКОКОВОЇ ІНФЕКЦІЇ У МИШЕЙ
}

\author{
Л.М. Лазаренко ${ }^{1}$, Л.П. Бабенко ${ }^{1}$, В.В. Мокрозуб ${ }^{1}$, О.М. Демченко \\ В.В. Біла', М.Я. Співак ${ }^{1,3}$
}
${ }^{1}$ Інститут мікробіологї і вірусології ім. Д.К. Заболотного Національної академї̈ наук Украӥни, вул. Ак. Заболотного, Київ, 03143, Украӥна
${ }^{2}$ Перинатальний иеентр, вул. Предславінська, 9, Київ, 03150, Україна
${ }^{3}$ ТОВ «ДІАПРОФ», вул. Світлищького, 35, Київ, 04123, Україна

\section{Резюме}

Мета. Метою цього дослідження було визначення впливу пробіотичного штаму L. casei IMB B-7280 та композицій L. casei IMB B-7280 - Bifidobacterium animalis $\mathrm{VKL}-$ B. animalis $\mathrm{VKB}(\mathrm{Lc}-\mathrm{VKL}-\mathrm{VKB})$ або B. animalis $\mathrm{VKL}-B$. animalis $\mathrm{VKB}$ (VKL - VKB), які вводили вагінально і перорально або лише перорально, на вагінальну мікробіоту та продукцію цитокінів за експериментальної вагінальної стафілококової інфекції у мишей лінії BALB/c. Методи. Пробіотичні бактерії або пробіотичні композиції вводили інфікованим стафілококом мишам одночасно перорально та вагінально або лише перорально. Матеріал із піхви висівали на селективні середовища; підраховували кількість колонієутворюючих одиниць, враховуючи, що одна така колонія відповідає одній бактерії. Концентрацію цитокінів у сироватці крові мишей визначали методом імуноферментного аналізу. Результати. Встановлено, що кількість аеробних і факультативно-анаеробних мікроорганізмів у піхві інфікованих стафілококом мишей зменшувалась у різні періоди спостереження після введення цього пробіотичного штаму та пробіотичних композицій одночасно у піхву і перорально або лише перорально. Також спостерігали збільшення кількості лактобацил і біфідобактерій у піхві цих мишей. Однак кількість коліморфних бактерій та мікроскопічних грибів була меншою, а кількість лактобацил більшою після одночасного вагінального і перорального введення L. casei IMB B-7280, а також композицій Lc - VKL - VKB або VKL - VKB інфікованим стафілококом мишам порівняно з пероральним введенням. Зміна мікробіоти піхви інфікованих стафілококом мишей, які отримували цей пробіотичний штам або пробіотичні композиції, відбувалася за підвищення рівня продукції інтерферону- $\gamma$ та інтерлейкіну-12, що сприяє розвитку Th1 типу імунної відповіді, а також зниження продукції прозапального цитокіну фактору некрозу пухлин- $\alpha$. Імуномодулювальна ефективність L. casei IMB B-7280 і композиції Lc - VKL - VKB також була вищою, якщо їх вводили інфікованим стафілококом мишам вагінально і перорально, ніж лише перорально. Висновки. L. casei IMB B-7280 і пробіотичні композиції $\mathrm{Lc}-\mathrm{VKL}$ - VKB або VKL - VKB можуть бути хорошими кандидатами для створення імунобіотиків для лікування урогенітальних інфекцій.

Ключові слова: лактобацили, біфідобактерії, мікробіота, піхва, стафілокок, цитокіни, миші. 


\title{
ДЕЙСТВИЕ ПРОБИОТИЧЕСКИХ БАКТЕРИЙ ПРИ ПЕРОРАЛЬНОМ И ВАГИНАЛЬНОМ ВВЕДЕНИИ НА ВАГИНАЛЬНУЮ МИКРОБИОТУ И ПРОДУКЦИЮ ЦИТОКИНОВ ПРИ ЭКСПЕРИМЕНТАЛЬНОЙ СТАФИЛОКОККОВОЙ ИНФЕКЦИИ У МЫШЕЙ
}

\author{
Л.Н. Лазаренко ${ }^{1}$, Л.П. Бабенко ${ }^{1}$, В.В. Мокрозуб ${ }^{1}$, О.Н. Демченко \\ В.В. Била', Н.Я. Спивак ${ }^{1,3}$
}

${ }^{1}$ Институт микробиологии и вирусологии им. Д.К. Заболотного Национальной академии наук Украины, ул. Ак. Заболотного, 154, Киев, 03143, Украина

${ }^{2}$ Перинатальный иентр, ул. Предславинская, 9, Киев, 03150, Украина

${ }^{3}$ ТОВ «ДИАПРОФ», ул. Светлицкого, 35, Киев, 04123, Украина

\section{Резюме}

Цель. Целью данного исследования было определение влияния пробиотического штамма L. casei ИМВ В-7280 и композиций L. casei ИМВ В-7280 - Bifidobacterium animalis $\mathrm{VKL}-B$. animalis $\mathrm{VKB}(\mathrm{Lc}-\mathrm{VKL}-\mathrm{VKB})$ или B. animalis $\mathrm{VKL}-B$. animalis VKB (VKL - VKB), которые вводили вагинально и перорально или только перорально, на вагинальную микробиоту и продукцию цитокинов при экспериментальной вагинальной стафилококковой инфекции у мышей линии $\mathrm{BALB} / \mathrm{c}$. Методы. Пробиотические бактерии или пробиотические композиции вводили инфицированным стафилококком мышам одновременно перорально и вагинально или перорально. Материал из влагалища высевали на селективные среды; подсчитывали количество колониеобразующих единиц, учитывая, что одна такая колония соответствует одной бактерии. Концентрацию цитокинов в сыворотке крови мышей определяли методом иммуноферментного анализа. Результаты. Установлено, что количество аэробных и факультативно-анаэробных микроорганизмов во влагалище инфицированных стафилококком мышей снижалось в различные периоды наблюдения после введения этого пробиотического штамма или пробиотических композиций одновременно во влагалище и перорально или только перорально. Также наблюдалось увеличение количества лактобацилл и бифидобактерий во влагалище этих мышей. Однако количество колиморфных бактерий и микроскопических грибов было меньшим, а количество лактобацилл было большим после одновременного вагинального и перорального введения $L$. casei ИМВ В-7280, а также композиций Lc - VKL - VKB или VKL - VKB инфицированным стафилококком мышам по сравнению с пероральным введением. Изменение микробиоты влагалища инфицированных стафилококком мышей, получавших этот пробиотический штамм или пробиотические композиции, происходило при повышении уровня продукции интерферона- $\gamma$ и интерлейкина- 12 , что способствует развитию Th1 типа иммунного ответа, а также при снижении продукции провоспалительного цитокина фактора некроза опухолей- $\alpha$. Иммуномодулирующая эффективность L. casei ИМВ В-7280 и композиции Lc - VKL - VKB также была выше, если их вводили инфицированным стафилококком мышам одновременно вагинально и перорально, чем только перорально. Выводы. Пробиотический штам L. casei ИМВ В-7280 и композиции $\mathrm{Lc}-\mathrm{VKL}-\mathrm{VKB}$ или VKL - VKB могут быть хорошими кандидатами для создания иммунобиотиков для лечения урогенитальных инфекций.

Ключевые слова: лактобациллы, бифидобактерии, микробиота, влагалище, стафилококк, цитокины, мыши. 
1. Hanson L, VandeVusse L, Jermé M, Abad CL, Safdar N. Probiotics for Treatment and Prevention of Urogenital Infections in Women: A Systematic Review. J Midwifery Womens Health. 2016; 61(3):339-55.

2. Bron PA, Kleerebezem M, Brummer RJ, Cani PD, Mercenier A, MacDonald TT, et al. Can probiotics modulate human disease by impacting intestinal barrier function? Br J Nutr. 2017;117(1):93-107.

3. Sebastián Domingo JJ. Review of the role of probiotics in gastrointestinal diseases in adults. Gastroenterol Hepatol. 2017;S0210-5705(17)30003-1.

4. Williamson CB, Burns CM, Gossard CM, Pizano JM, Dolan KE, Finley HJ, et al. Probiotics and Disease: A Comprehensive Summary-Part 3, Cardiometabolic Disease and Fatigue Syndromes. Integr Med (Encinitas). 2017;16(1):30-41.

5. Reid $G$. The potential role of probiotics in pediatric urology. J Urol. 2002;168 (4 Pt 1):1512-1517.

6. Homayouni A, Bastani P, Ziyadi S, Mohammad-Alizadeh-Charandabi S, Ghalibaf M, Mortazavian AM, et al. Effects of probiotics on the recurrence of bacterial vaginosis: a review. J Low Genit Tract Dis. 2014;18(1):79-86.

7. Santos CM, Pires MC, Leão TL, Hernández ZP, Rodriguez ML, Martins AK, et al. Selection of Lactobacillus strains as potential probiotics for vaginitis treatment. Microbiology. 2016;162(7):1195-207.

8. Macklaim JM, Clemente JC, Knight R, Gloor GB, Reid G. Changes in vaginal microbiota following antimicrobial and probiotic therapy. Microb Ecol Health Dis. 2015; 14;26:27799.

9. Shida K, Nanno M, Nagata S. Flexible cytokine production by macrophages and T-cells in response to probiotic bacteria: a possible mechanism by which probiotics exert multifunctional immune regulatory activities. Gut Microbes. 2011;2(2):109-114.

10. Haruki Kitazawa, Julio Villena, Susana Avarez, editors. Probiotics: immunobiotics and immunogenic. New York: CRC Press; 2014.

11. House Robert V, Descotes Jacques, editors. Cytokines in Human Health. Immunotoxicology, Pathology, and Therapeutic Applications Immunotoxicology, Pathology, and Therapeutic Applications. New Jersey: Humana Press Inc; 2007.

12.Lazarenko L, Babenko L, Shynkarenko-Sichel L, Pidgorskyi V, Mokrozub V, Voronkova $O$, et al. Antagonistic action of Lactobacilli and Bifidobacteria in relation to Staphylococcus aureus and their influence on the immune response in cases of intravaginal staphylococcosis in mice. Probiotics \& Antimicrob. Prot. 2012;4(2):78-89.

13. Shirobokov VP, Jankowski DS, Dyment GS. [Microbial ecology of the human with color atlas]. Textbook. K. Ruta-tours, 2010. Russian

14. Strus M, Chmielarczyk A, Kochan P, Adamski P, Chetmicki Z, Chetmicki A, et al. Studies on the effects of probiotic Lactobacillus mixture given orally on vaginal and rectal colonization and on parameters of vaginal health in women with intermediate vaginal flora. Eur J Obstet Gynecol Reprod Biol. 2012;163(2):210-215.

15. Hutchins RG, Bailey CS, Jacob ME, Harris TL, Wood MW, Saker KE, et al. The effect of an oral probiotic containing lactobacillus, bifidobacterium, and bacillus species on the vaginal microbiota of spayed female dogs. J Vet Intern Med. 2013;27(6):13681371.

16. Balzaretti S, Taverniti V, Rondini G, Marcolegio G, Minuzzo M, Remagni MC, et al. The vaginal isolate Lactobacillus paracasei LPC-S01 (DSM 26760) is suitable for oral 
administration. Front Microbiol. 2015;15;6:952.

17. Reid G, Bruce $A W$, Taylor M. Instillation of Lactobacillus and stimulation of indigenous organisms to prevent recurrence of urinary tract infections. Microecol Ther. 1995;23:3245.

18. Reid G, Bruce AW, Fraser N, Heinemann C, Owen J, Henning B. Oral probiotics can resolve urogenital infections. FEMS Immunol Med Microbiol. 2001;30(1):49-52.

19. Bruce $A W$, Reid $G$. Intravaginal instillation of lactobacilli for prevention of recurrent urinary tract infections. Can J Microbiol. 1988;34(3):339-343.

20. Heczko PB, Tomusiak A, Adamski P, Jakimiuk AJ, Stefański G, Mikołajczyk-Cichońska A, et al. Supplementation of standard antibiotic therapy with oral probiotics for bacterial vaginosis and aerobic vaginitis: a randomised, double-blind, placebo-controlled trial. BMC Womens Health. 2015;3;15:115.

21. Szajewska H, Kotowska M, Mrukowicz JZ, Armanska M, Mikolajczyk W. Efficacy of Lactobacillus GG in prevention of nosocomial diarrhea in infants. J Pediatr. 2001;138(3):361-365.

22. Cadieux P, Burton J, Gardiner G, Braunstein I, Bruce AW, Kang CY, et al. Lactobacillus strains and vaginal ecology. JAMA. 2002;287(15):1940-1941.

23. Vitali B, Cruciani F, Baldassarre ME, Capursi T, Spisni E, et al. Dietary supplementation with probiotics during late pregnancy: outcome on vaginal microbiota and cytokine secretion. BMC Microbiol. 2012;18;12:236.

24. Babenko LP, The effect of probiotic strains of lactobacilli and bifidobacteria on a range of microbiota and immunologic reactivity of the organism in cases of staphylococcal infection of the urogenital tract: thesis for obtaining PhD degree in biology: Kyiv, 2015. 24 p. Ukrainian.

Отримана 22.03.2017 